\title{
Isolation and characterization of rat sperm tail outer dense fibres and comparison with rabbit and human spermatozoa using a polyclonal antiserum
}

\author{
Y. H. Kim ${ }^{1}$, J. R. McFarlane ${ }^{2 *}$, M. K. O'Bryan ${ }^{1}$, G. Almahbobi ${ }^{1}$, P. D. Temple-Smith ${ }^{3}$ \\ and D. M. de Kretser ${ }^{1}$ \\ ${ }^{1}$ Institute of Reproduction and Development, and ${ }^{3}$ Department of Anatomy, Monash University, Clayton Australia 3168; \\ and ${ }^{2}$ Department of Physiology, University of New England, Armidale, NSW Australia 2351
}

\begin{abstract}
Rat outer dense fibres were isolated from cauda epididymal spermatozoa using mechanical and chemical dissection methods. Sperm tail isolation procedures were monitored by phase-contrast microscopy and the purity of the outer dense fibres was verified by electron microscopy. SDS-PAGE of isolated outer dense fibres revealed at least nine Coomassie brilliant blue stained bands, and 12 silver staining bands. The most abundant proteins were a large band between 26.5 and $32.5 \mathrm{kDa}$, and $84 \mathrm{kDa}$, $21.5 \mathrm{kDa}$ and $15.5 \mathrm{kDa}$ bands. The amino acid composition of the total rat outer dense fibres and seven isolated proteins showed similar compositions, being abundant in aspartic and glutamic acid, serine, glycine and leucine. However, the content of cysteine and proline was highly variable among the isolated proteins. Immunofluorescence microscopy demonstrated that a polyclonal antiserum to isolated rat outer dense fibres showed positive staining localized to the mid-piece of rat and rabbit spermatozoa. However, there was crossreactivity in the principal piece as well as the mid-piece of the human spermatozoa. The antiserum also showed crossreactivity in the perforatorium of rat sperm heads and the acrosome and equatorial segment of rabbit sperm heads. These data indicate that it is technically possible to isolate proteins from the outer dense fibres that will enable further studies of the amino acid sequences of sperm tail proteins.
\end{abstract}

\section{Introduction}

The outer dense fibres (ODFs) are located throughout most of the length of the sperm tail and surround the axoneme in the middle piece of the flagellum and in the more distal principal piece (Fawcett, 1975). However, in human spermatozoa, the ODFs extend along $50-60 \%$ of the principal piece and gradually attenuate (Holstein and Roosen-Runge, 1981; Haidl et al., 1991). In the mid-piece there are nine ODFs, each one associated with a microtubule doublet of the axoneme. In the principal piece, the number of ODFs is reduced to seven, and these decrease progressively in size distally (Fawcett, 1970, 1975). The ODFs associated with the axonemal microtubules numbered 3 and 8 terminate at the annulus, which marks the distal end of the middle piece. The functional role of the ODFs remains to be determined; however, it has been suggested that they provide rigidity and directionality to tail movement and protect against shearing forces during transit through the epididymis (Baltz et al., 1990).

Methods for isolating ODFs have been developed using

* Correspondence.

Revised manuscript received 23 December 1998. chemical dissection of spermatozoa using selective solubilization of components by sodium dodecyl suphate (SDS) and dithiothreitol (DTT), together with mechanical techniques, such as sonication and density gradient centrifugation. SDS-PAGE has been used to characterize the proteins in the outer dense fibres from bull (Baccetti et al., 1973), rat (Price, 1973; Olson and Sammons, 1980; Vera et al., 1984; Oko, 1988) and human spermatozoa (Haidl et al., 1991). Conflicting information on protein composition, as determined by SDS-PAGE, has been reported for rat ODFs: (i) five major bands of $84 \mathrm{kDa}, 80 \mathrm{kDa}, 32-26 \mathrm{kDa}, 20 \mathrm{kDa}$ and $14.4 \mathrm{kDa}$ (Oko, 1988); (ii) four bands of $87 \mathrm{kDa}, 25 \mathrm{kDa}, 19 \mathrm{kDa}$ and $12 \mathrm{kDa}$ (Olson and Sammons, 1980); and (iii) six major bands of $87 \mathrm{kDa}, 30.4 \mathrm{kDa}, 26 \mathrm{kDa}, 18.4 \mathrm{kDa}, 13 \mathrm{kDa}$ and $11.5 \mathrm{kDa}$ (Vera et al., 1984). The amino acid compositions of the major components of rat ODFs have been shown to contain a high content of serine, aspartic and glutamic acids, proline, cysteine, leucine, and tyrosine (Vera et al., 1984). Vera $e t$ al. (1984) indicated, by isolating only the major bands of ODF to determine their amino acid composition, that the major components of rat sperm tail ODF are a unique family of phosphoproteins that are phosphorylated at serine residues.

Despite the fact that individual ODF protein bands have been isolated, progress in identifying the genes that encode 
them have been hampered by the extreme insolubility of these proteins and the difficulty in obtaining amino terminal amino acid sequences. The gene sequence encoding only three ODF proteins are known to date. The rat and human homologue of the Drosophila germ cell product, Mst(3)gl-9, was found to encode a 244 amino acid polypeptide with a total amino acid composition similar to that of a $26-32 \mathrm{kDa}$ protein of the rat ODF (Burfeind and Hoyer-Fender, 1991; Burfeind et al., 1993). Western blotting with a synthetic peptide antiserum detected a major $31 \mathrm{kDa}$ ODF protein. This protein was shown to interact with the leucine zipper motifs of another rat ODF protein, Odf84, using interactional cloning technology (Shao et al., 1997). A third ODF gene, Odf2, which encodes highly variable transcripts that translate into proteins of $65-70 \mathrm{kDa}$, was identified by screening a rat testis expression library with an ODF-specific antisera (Brohmann et al., 1997).

The present study was undertaken to isolate the major and minor protein components of ODF in rat spermatozoa and to determine their amino acid composition. Furthermore, studies were undertaken to compare the characteristics of the proteins comprising the ODF of rat, rabbit and human spermatozoa using a polyclonal antibody raised against isolated rat ODF.

\section{Materials and Methods}

\section{Experimental animals}

Adult male Sprague-Dawley rats (90-110 days old) from the Central Animal House, Monash University were killed by $\mathrm{CO}_{2}$ anaesthesia. Rabbit spermatozoa were collected from adult New Zealand white rabbits using an artificial vagina, and human spermatozoa with normal morphological and motility characteristics were obtained from the Andrology Department at Monash Medical Centre.

These investigations were approved by Monash University Standing Committee on Ethics in Animal Experimentation and conformed to the $\mathrm{NH} \& \mathrm{MRC} / \mathrm{CSIRO} / \mathrm{AAC}$ Code of Practice for the Care and Use of Animals for Experimental Purposes.The studies were also approved by the Human Ethics Committee of the Monash Medical Centre and conform to the NH \& MRC guidelines.

\section{Preparation of rat sperm tails}

A modification of the original method of Calvin (1976) was used to isolate sperm tails from rat spermatozoa. The rat caudae epididymides were dissected and spermatozoa were released by mincing with razor blades in several drops of $0.05 \mathrm{~mol}$ sodium phosphate buffer $1^{-1}, \mathrm{pH} 7.5,0.15 \mathrm{~mol}$ $\mathrm{NaCl}^{-1}$, containing $0.2 \mathrm{mmol}$ phenylmethylsulfonyl fluoride $1^{-1}$ (PBS-PMSF). Washed spermatozoa were decapitated by sonication (Sonifier model B-30, Branson Sonic Power Co., Shelton, CT) at $30 \%$ output for $30 \mathrm{~s}$ twice at $4^{\circ} \mathrm{C}$. After washing with PBS-PMSF, the decapitated spermatozoa were suspended in $65 \%(\mathrm{w} / \mathrm{v})$ sucrose in PBS-PMSF and, using a Beckman SW 28 swinging bucket rotor, centrifuged through a sucrose step gradient $(75,70,65 \%(\mathrm{w} / \mathrm{v}))$ at $100000 \mathrm{~g}$ for
$80 \mathrm{~min}$. The sperm tails were aspirated from the $65-70 \%$ interface. At this stage, the sperm tails had approximately $5 \%$ head contamination. The sperm tails were suspended in PBS containing $0.2 \mathrm{mmol} \mathrm{PMSF}^{-1}$ and then layered on a sucrose step gradient $(65,75 \%)$ and centrifuged at $100000 \mathrm{~g}$ for $60 \mathrm{~min}$ to increase the purity of the preparation. Sperm tails aspirated from the $65-75 \%$ sucrose interface were washed and centrifuged at $10000 \mathrm{~g}$ for $10 \mathrm{~min}$ in a Sorvall-SS34 centrifuge with PBS containing $0.2 \mathrm{mmol} \mathrm{PMSF}_{\mathrm{l}} \mathrm{l}^{-1}$. The sperm tails, containing $<1 \%$ head contamination, as judged by phase-contrast microscopy, were used subsequently for isolation of the ODF.

\section{Isolation of rat sperm outer dense fibres}

The procedure for isolating the ODF from sperm tails was a modification of the method of Oko (1988). Isolated sperm tails were suspended in $1 \%(\mathrm{w} / \mathrm{v})$ SDS, $2 \mathrm{mmol}^{\mathrm{DTT}} \mathrm{l}^{-1}$ and $25 \mathrm{mmol}$ Tris- $\mathrm{HCl} \mathrm{l}^{-1}$ at $\mathrm{pH} 8.0$ for $70 \mathrm{~min}$ with shaking at room temperature. The insoluble fraction was suspended in $25 \mathrm{mmol}$ Tris- $\mathrm{HCl} \mathrm{l} \mathrm{l}^{-1}(\mathrm{pH} 8.0)$ containing $25 \%(\mathrm{w} / \mathrm{v})$ sucrose and layered on top of a sucrose step gradient of $25,50,75 \%$ $(\mathrm{w} / \mathrm{v})$. After centrifugation at $100000 \mathrm{~g}$ for $50 \mathrm{~min}$, the insoluble pellet was removed from the $50-75 \%$ sucrose interface and washed with $25 \mathrm{mmol}$ Tris- $\mathrm{HCl} \mathrm{l}^{-1}$ at $50000 \mathrm{~g}$ for $20 \mathrm{~min}$. The final purified ODF was solubilized in $25 \mathrm{mmol}^{\mathrm{Tris}}-\mathrm{HCl} \mathrm{l}^{-1}$,

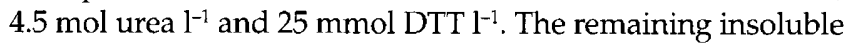
material, containing a minor contamination of sperm heads, was removed by centrifugation. The isolation of the ODF was monitored by phase-contrast microscopy and the purity was verified by electron microscopy.

\section{Preparation of sperm proteins}

Rat, rabbit and human spermatozoa were solubilized in $4.5 \mathrm{~mol}$ urea $\mathrm{l}^{-1}, 2 \%(\mathrm{w} / \mathrm{v}) \mathrm{SDS}, 25 \mathrm{mmol}^{\mathrm{DTT}} \mathrm{l}^{-1}$ by shaking at room temperature for $5 \mathrm{~h}$. The insoluble gel-like material was removed by centrifugation at $10000 \mathrm{~g}$ for $20 \mathrm{~min}$. The protein content was estimated using the Bio-Rad DC protein assay (Bio-Rad Laboratories, Hercules, CA), which is similar to that described by Lowry et al. (1951), but is more tolerant of detergents.

\section{Electron microscopy}

Samples from each step of the isolation procedure were placed into Eppendorf microfuge tubes and, after washing with PBS, were centrifuged in a Beckman microfuge for $2 \mathrm{~min}$. The resultant sperm pellets were fixed in $2.5 \%(\mathrm{v} / \mathrm{v})$ glutaraldehyde in 0.1 mol sodium cacodylate $\mathrm{l}^{-1}$ buffer, $\mathrm{pH}$ 7.4 , overnight at $4^{\circ} \mathrm{C}$, and then gently resuspended in cacodylate buffer. After centrifugation, the sperm pellets were post-fixed in $1 \%(\mathrm{v} / \mathrm{v})$ osmium tetroxide. After dehydration in a series of alcohol solutions of 50, 70, 95 and $100 \%$ ethanol, samples were embedded in Epon 812 and allowed to polymerize at $60^{\circ} \mathrm{C}$. Thin sections were cut with a glass or diamond knives on a Reichert OM U3 
ultramicrotome, mounted on uncoated 150 mesh copper grids and stained with uranyl acetate for $5 \mathrm{~min}$ and then lead citrate for $10 \mathrm{~min}$. Each specimen was examined on a Jeol II electron microscope at $60 \mathrm{KV}$. Electron micrographs were taken using Kodak electron microscope film 4489.

\section{Antibody preparation}

Approximately $75 \mu \mathrm{g}$ of solubilized ODF was emulsified in an equal volume of Freund's complete adjuvant (Commonwealth Serum Laboratories, Melbourne, Vic) and injected s.c. into multiple sites around the neck and shoulder region of New Zealand white rabbits using a $2 \mathrm{ml}$ syringe fitted with a 25 gauge needle. These rabbits were boosted with $25 \mu \mathrm{g}$ of each protein in an equal volume of Freund's incomplete adjuvant at 2 week intervals for 8 weeks. Serum was collected from two rabbits: JMR3 and JMR4.

\section{SDS-PAGE}

The apparent molecular sizes of the ODF protein components were determined using $12.5 \%(\mathrm{w} / \mathrm{v})$ SDSpolyacrylamide mini gels (Laemmli, 1970) under reducing conditions; $10 \mu \mathrm{g}$ protein per well was used for Coomassie brilliant blue staining and $1 \mu \mathrm{g}$ protein for silver staining (Wray et al., 1981). The molecular size was calibrated using molecular weight standards (Novex, San Diego, CA).

\section{Western blotting}

Rat, rabbit and human spermatozoa were solubilized in $4.5 \mathrm{~mol}^{-1} \mathrm{rrea}^{-1}, 2 \%(\mathrm{w} / \mathrm{v})$ SDS and $25 \mathrm{mmol}^{\mathrm{DDT}} \mathrm{l}^{-1}$ and the isolated sperm proteins were separated from the gel-like DNA material by centrifugation at $10000 \mathrm{~g}$ for $20 \mathrm{~min}$. Approximately $10 \mathrm{\mu g}$ per lane of purified rat ODF, rat fibrous sheath (FS; Kim et. al., 1995) and whole rat, rabbit and human sperm proteins were run on $12.5 \%(\mathrm{w} / \mathrm{v})$ SDS-PAGE. The proteins were transferred onto nitrocellulose membrane (BA

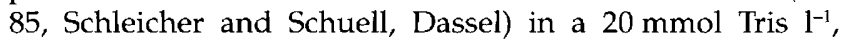
150 mmol glycine $\mathrm{l}^{-1}$ buffer containing $20 \%$ methanol at $60 \mathrm{~V}$ overnight (Towbin et al., 1979). The transfer buffer was then changed to $25 \mathrm{mmol}$ phosphate buffer $\mathrm{l}^{-1}, \mathrm{pH} 6.5,20 \%$ methanol, and transferred at $30 \mathrm{~V}$ for a further $5 \mathrm{~h}$. The excess protein binding sites on the membrane were blocked with $0.05 \mathrm{~mol}$ phosphate buffer $\mathrm{l}^{-1}, \mathrm{pH} 7.5,0.15 \mathrm{~mol} \mathrm{NaCl}^{-1}$ (PBS), containing $1 \%(\mathrm{w} / \mathrm{v})$ non-fat milk powder for $1 \mathrm{~h}$. The membrane was probed overnight at room temperature with antiserum JMR3 or pre-immune serum diluted to $1: 1000$ with PBS containing 1\% (w/v) Tween 20 (Sigma, St Louis, $\mathrm{MO}$ ). The membrane was then incubated for $3 \mathrm{~h}$ with a biotinylated sheep anti-rabbit immunoglobulin antiserum (Silenus Laboratories, Melbourne, Victoria) diluted 1:3000 in PBS-Tween. The membrane was incubated for a further $1 \mathrm{~h}$ with strepavidin-HRP (Silenus) diluted to $1: 8000$ in PBS-Tween. The blot was developed with $10 \mathrm{mg} 3,3^{\prime}-$ diaminobenzidine (DAB, Sigma) diluted in $15 \mathrm{ml}$ of $20 \mathrm{mmol}$ Tris- $\mathrm{HCll}^{-1}$, pH 7.5, $0.15 \mathrm{~mol} \mathrm{NaCl}^{-1}$.

\section{Isolation of protein components}

Isolated whole ODF proteins were excised from preparative SDS-PAGE gels run under reducing conditions, and electroeluted (Hunkapiller et. al., 1983) as described by Kim et al. (1995). The purity of the bands was determined by SDS-PAGE and silver staining and the eluted proteins were stored at $-20^{\circ} \mathrm{C}$.

\section{Amino acid composition and sequencing}

Isolated ODF or purified ODF proteins were precipitated with eight volumes of $100 \%$ cold methanol $\left(-20^{\circ} \mathrm{C}\right)$; the precipitate was resuspended in $20 \mu \mathrm{l}$ of pure water and precipitated for a second time with cold methanol. The samples were then lyophilized and hydrolysed in a vacuum in constantly boiling $6 \mathrm{~mol} \mathrm{HCl}^{-1}$ containing $0.2 \%(\mathrm{w} / \mathrm{v})$ phenol for $22 \mathrm{~h}$ at $110^{\circ} \mathrm{C}$. Samples were analysed using the Millipore Picotag method (Millipore, Bedford, MA; Cohen and Strydom, 1988). The losses incurred by the hydrolysis, as measured in control proteins, were minimal (Stanton et al., $1992)$ except in the case of tyrosine $(26 \%)$. Methionine and cystine (including cysteine) content was estimated by oxidizing the samples to methionine sulphone and cysteic acid, respectively, using performic acid. Samples were analysed at least twice in separate hydrolysates and the results were averaged. The average coefficient of variation between runs was $<2 \%$.

The most abundant isolated ODF proteins, the 84,66 and $30 \mathrm{kDa}$ proteins, were sequenced for five cycles, and amino acids were identified by an online Applied Biosystems $470 \mathrm{~A}$ gas phase sequencer (Applied Biosystems Inc, Foster, CA). Sequencing of the amino termini of these proteins, either directly or cut from a PVDF membrane (Immobilon-PSQ, Millipore Corp, Bedford, MA), was unsuccessful, presumably due to the amino terminus being blocked.

\section{Indirect immunofluoresence microscopy}

Rat cauda epididymal spermatozoa and ejaculated rabbit and human spermatozoa were washed in PBS-PMSF, spotted on glass slides precoated with poly-L-lysine and fixed with $2 \%(\mathrm{v} / \mathrm{v})$ formaldehyde for $30 \mathrm{~min}$ at $4^{\circ} \mathrm{C}$, and then processed for indirect immunofluorescence as described by Kim et al. (1995) and Almahbobi and Hall (1993). In brief, the attached spermatozoa were extracted with $1 \%(\mathrm{v} / \mathrm{v})$ Triton $X-$ 100 in $10 \mathrm{mmol}$ Pipes $1^{-1}, \mathrm{pH} 6.8,0.1 \mathrm{~mol} \mathrm{NaCl} 1^{-1}, 3 \mathrm{mmol}$ $\mathrm{MgCl}, 1^{-1}, 20 \%$ (w/v) sucrose, for $5 \mathrm{~min}$ at $4^{\circ} \mathrm{C}$. Nonspecific binding and autofluorescence were reduced by treating the spermatozoa with $1.5 \%(\mathrm{w} / \mathrm{v})$ glycine for $20 \mathrm{~min}$ and $1 \%(\mathrm{w} / \mathrm{v})$ sodium borohydride for $30 \mathrm{~min}$. The spermatozoa were then incubated with the anti-ODF antiserum (JMR 3), diluted $1: 100$ in PBS for $60 \mathrm{~min}$, and then with a sheep anti-rabbit immunoglobulin conjugated to fluorescein isothiocyanate (Silenus, 1:50) for $30 \mathrm{~min}$. Nonspecific staining was determined by replacing the primary antiserum with preimmune rabbit serum or with PBS. Autofluorescence and aldehyde-induced fluorescence were tested by omitting the 
second antibody before and after fixation. Photography and printing were performed at the same settings for all fields.

\section{Tissue preparation and immunohistochemistry}

Adult male Sprague-Dawley rats were fixed by perfusion with Bouin's fixative via the dorsal aorta. Testes were emersion-fixed for $3 \mathrm{~h}$ and then processed into paraffin wax using standard techniques. Sections $(5 \mu \mathrm{m})$ were cut and floated onto 3-aminopropyltriethoxysilane (Sigma)-coated slides. Sections were dewaxed and rehydrated using Histosol (Interpath Services, West Heidelberg, Melbourne, Victoria) and graded ethanols, respectively. Endogenous peroxidase activity was eliminated by a $15 \mathrm{~min}$ incubation in $3 \%(\mathrm{v} / \mathrm{v})$ hydrogen peroxide. Antibody access was improved using an antigen retrieval process: slides were immersed in $50 \mathrm{mmol}$ glycine- $\mathrm{HCl}$ buffer $\mathrm{1}^{-1}, \mathrm{pH} 3.5$, and exposed to microwaves at $2.25 \mathrm{~W} \mathrm{ml}^{-1} \mathrm{~min}^{-1}$ for $2 \mathrm{~min}$ and then at $0.3 \mathrm{~W}$ $\mathrm{ml}^{-1} \mathrm{~min}^{-1}$ for $8 \mathrm{~min}$ (Akai MW-420 microwave, Akai Electric Co., Korea). The solution was allowed to cool before sections were washed in PBS. Nonspecific binding was eliminated by preincubating sections in the blocking solution provided in the universal-labelled streptavidin (LSAB)-horseradish peroxidase kit (Dako Co., Botany, NSW). Sections were rinsed in PBS before incubation in a 1:500 dilution of the ODF antiserum in $0.1 \%$ BSA-PBS overnight at $4^{\circ} \mathrm{C}$. Excess antibody was removed by washing twice in PBS. Bound antibody was detected using a horseradish peroxidase conjugated antirabbit serum ( $(1: 100$, Silenus) for $60 \mathrm{~min}$ at room temperature. Antibody binding was visualized by incubating sections with DAB. Some sections were lightly counterstained with Meyer's haematoxylin (Sigma) to determine the stage of spermatogenesis of specific tubules. Sections were dehydrated through graded ethanol and mounted under glass coverslips using DPX mounting solution (BDH Laboratory Supplies, Poole). As a negative control, primary antibody was replaced by nonimmune rabbit serum.

\section{Results}

\section{Isolation of rat outer dense fibres}

After treatment with SDS and DTT, the sperm tail pellet was homogeneous as verified by phase-contrast microscopy. Sperm tail components, including plasma membrane, axoneme, fibrous sheath and mitochondrial sheath, were solubilized and the ODFs were isolated (Fig. 1). The purity of the isolated ODF was $>95 \%$.

\section{SDS-PAGE and western blotting}

Isolated rat ODF resolved with SDS-PAGE into at least seven different major and minor Coomassie brilliant bluestained protein bands (Fig. 2a) $(84,79,66.2,57.2,29,21.5$ and $15.5 \mathrm{kDa}$ ), with additional bands $(190,150,54,48.5$ and $44.6 \mathrm{kDa}$ ) revealed after silver staining (Fig. $2 \mathrm{~b}$ ). The most abundant proteins were a large band between 26.5 and

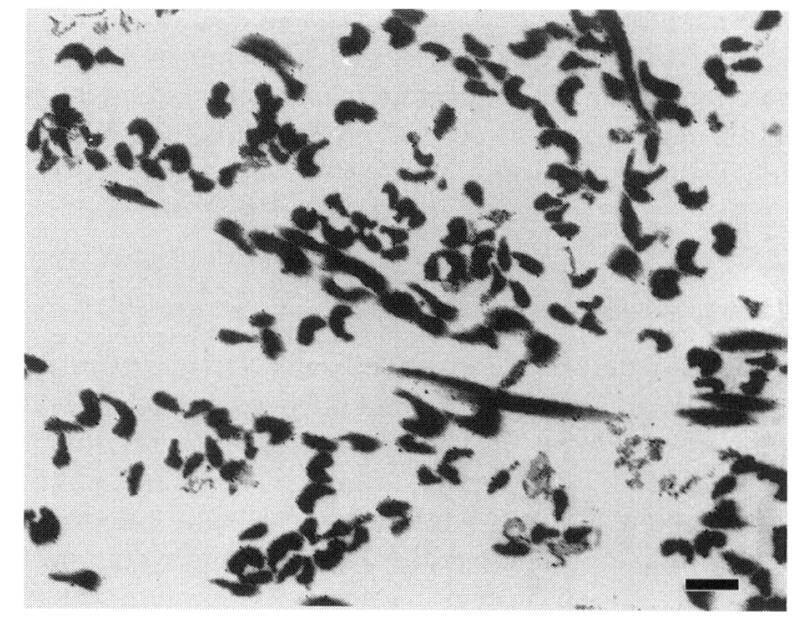

Fig. 1. Electron micrograph of cross and oblique sections of isolated rat sperm tail outer dense fibres. Scale bar represents $400 \mathrm{~nm}$.

$32.5 \mathrm{kDa}, 84.0,21.5$ and $15.5 \mathrm{kDa}$ bands. These results were very similar to those of previous reports (Oko,1988; Vera et al., 1984; Olson and Sammons 1980) (Table 1).

SDS-PAGE followed by electroelution isolated ten of the ODF proteins $(66.2,57.2,54.0,48.5,44.6,32.5,29.0,26.0,21.5$ and $15.5 \mathrm{kDa}$ ) (Fig. 2c, lanes 1-10). Three of these, the 32.5, 29.0 and $26.0 \mathrm{kDa}$ bands, were cut from the broad band at 26.5-32.5 kDa. The two high molecular mass bands at 190 and $150 \mathrm{kDa}$, which stained poorly with Coomassie blue, could not be cut from the gel. The $84.0 \mathrm{kDa}$ protein and the $21.5 \mathrm{kDa}$ proteins could not be isolated from the gel slices by electroelution. Although isolated from gel slices, with storage, the 54 (lane 3) and $48.5 \mathrm{kDa}$ (lane 4) proteins began to show a band at $26 \mathrm{kDa}$, which was unlikely to be due to contamination.

Western blotting showed a pattern of staining with the ODF antiserum that reflected the apparent abundance of the individual protein bands in the isolated rat ODF after SDSPAGE (Fig. 3). Crossreactivity of the ODF antiserum with purified FS was very weak and showed only a slight crossreactivity with proteins at 26 and $32 \mathrm{kDa}$ in the rat FS protein preparation (Fig. 3, lane 5), indicating that the FS preparation may have had a slight contamination with ODF or that there are common epitopes. The 26-32 kDa polypeptides of the human, rabbit and rat sperm proteins were stained with the antiserum. The 66 and $45 \mathrm{kDa}$ proteins in human and rat spermatozoa were also stained, and there was additional staining at $84 \mathrm{kDa}$ in the rat sperm proteins. No staining was observed when pre-immune serum was used instead of immune serum (data not shown).

\section{Amino acid composition and sequencing of rat outer dense fibres}

The amino acid composition of rat ODF and seven isolated proteins are compared (Table 2). All of these proteins have a similar amino acid composition, being abundant in aspartic 
Table 1. Comparison of molecular masses of major rat sperm outer dense fibre polypeptides in different studies

\begin{tabular}{lcccc}
\hline Polypeptide & $\begin{array}{c}\text { Olson and } \\
\text { Sammons (1980) }\end{array}$ & Vera et al. (1984) & Oko (1988) & Present study \\
\hline a & 87000 & 87000 & 84000 & 84000 \\
b & & 80000 & 79000 \\
c & & & & 66200 \\
d & 25000 & 30400 & 32000 & 57200 \\
& & 26000 & 26000 & 32000 \\
e & 19000 & 18400 & 29000 \\
f & 12000 & 13000 & 20000 & 26000 \\
g & & 11500 & 14400 & 15500 \\
\hline
\end{tabular}

${ }^{a-g E a c h ~ l i n e ~ r e p r e s e n t s ~ m o l e c u l a r ~ m a s s e s ~ o f ~ p o l y p e p t i d e s ~ t h a t ~ p r e s u m a b l y ~ c o r r e s p o n d ~ t o ~ e a c h ~ o t h e r . ~}$

(a)

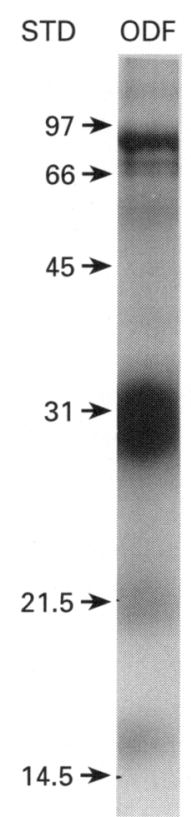

(b)

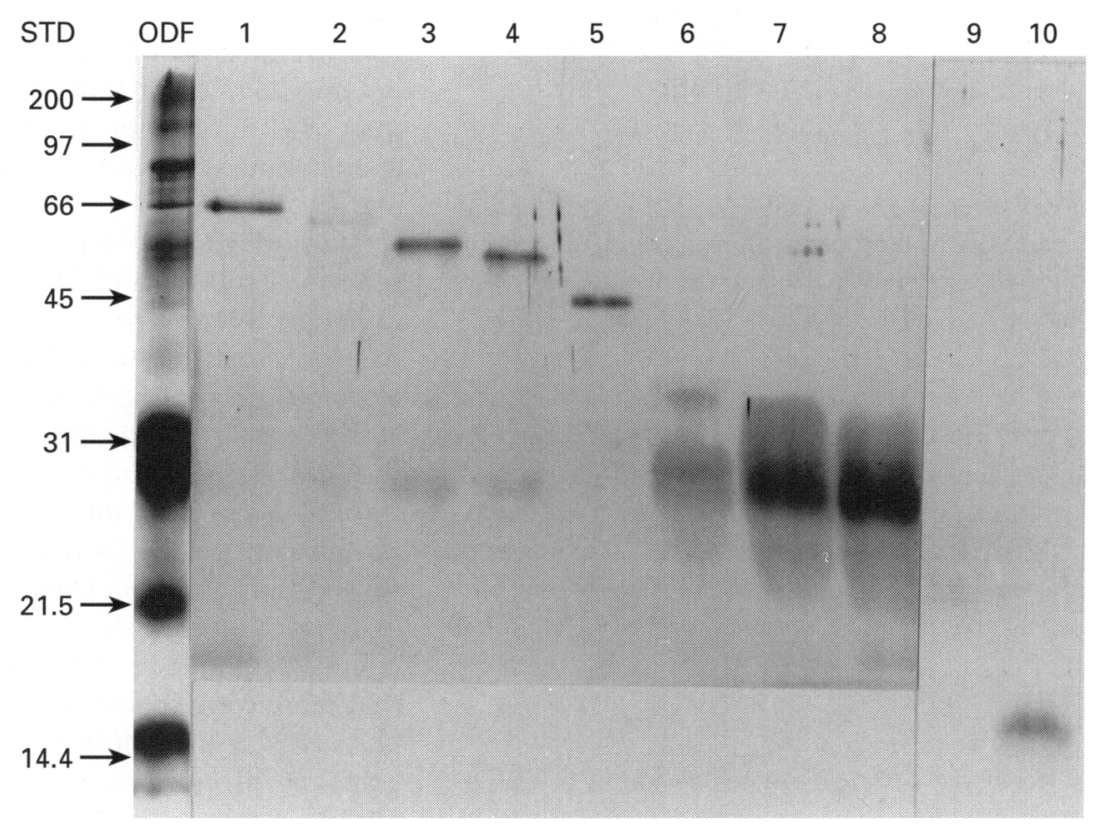

Fig. 2. SDS-PAGE gels (12.5\%) of rat sperm tail total outer dense fibre proteins, stained with (a) Coomassie brilliant blue, (b) silver stain and (c) silver-stained isolated individual proteins, showing ten isolated bands including 66.2 (lane 1), 57.2 (lane 2), 54 (lane 3), 48.5 (lane 4), 44.6 (lane 5), 32.5 (lane 6), 29 (lane 7), 26.5 (lane 8), 21.5 (lane 9) and 15.5 kDa (lane 10).

and glutamic acid, serine, glycine and leucine. However, the content of cysteine and proline were highly variable among the isolated proteins.

The amino terminal amino acid sequencing of the most abundant isolated proteins, the 84,66 and $30 \mathrm{kDa}$ ODF proteins, was unsuccessful, presumably due to blocking of the amino terminus which, despite variations in the sequencing conditions, prevented all attempts to sequence these proteins.

The amino acid composition results of rat sperm outer dense fibres in the present study were compared with the results of two previous studies (Table 3).

\section{Immunofluorescence microscopy}

Strong positive staining was observed in the mid-piece of rat (Fig. 4b) and rabbit spermatozoa (Fig. 4f) when an antiserum raised to highly purified rat ODF was used, with much less intense staining in the principal piece of both sperm types (Fig. 4b,f). In human spermatozoa, strong positive staining was observed in both the mid-piece and the principal piece (Fig. 4d). The antiserum also showed crossreactivity in the perforatorium of rat sperm heads (Fig. $4 \mathrm{~b}, \mathrm{c})$, and the acrosome and equatorial segment of rabbit sperm heads (Fig. 4f). Weak staining of the postacrosomal 


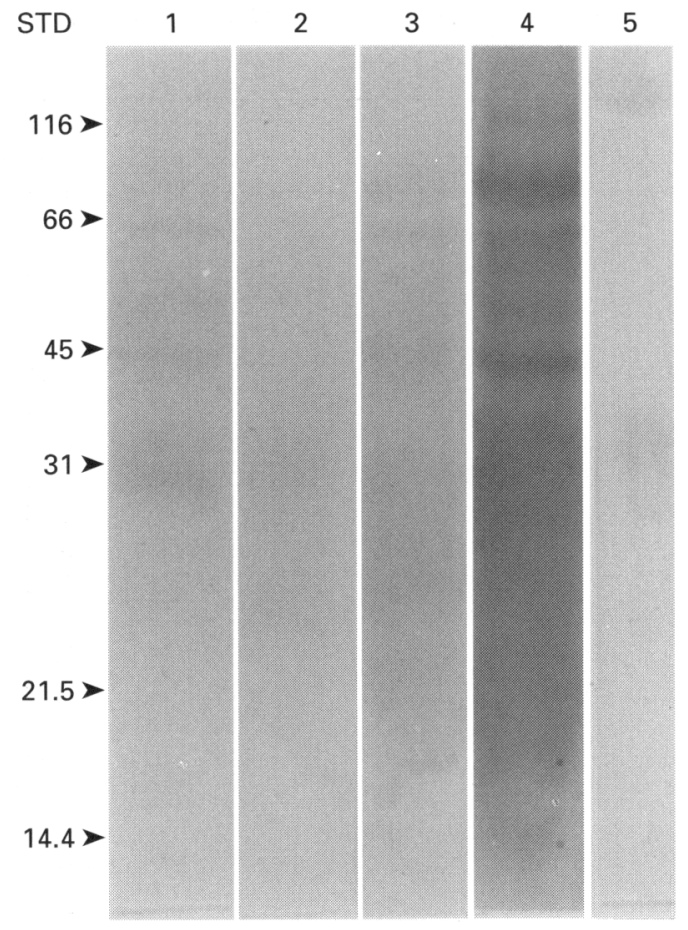

Fig. 3. Western blot of human (lane 1), rabbit (lane 2) and rat (lane 3) spermatozoa, rat sperm tail outer dense fibre (4) and rat fibrous sheath (lane 5) probed with a polyclonal antiserum against rat sperm tail outer dense fibre.

segment of some, but not all, sperm heads was observed in human spermatozoa (Fig. 4d). When preimmune serum was used, no positive staining was observed, except for a weak autofluorescent signal in the mid-piece of all three sperm types (data not shown).

\section{Immunohistochemistry}

Immunohistochemistry of adult rat testes using the ODF antisera displayed a stage- and cell-specific distribution of staining. Immunostaining was limited to elongating spermatids. Staining was first detected within the cytoplasm of step 11 spermatids, and increased in intensity up to step 15 spermatids. Subsequent to step 15, the intensity of staining was maintained (Fig. 5). Immunostaining was not detected in any Sertoli cells, Leydig cells, peritubular cells, macrophages or germ cells developmentally less mature than step 11 spermatids.

\section{Discussion}

This study demonstrates that all the major protein and a large number of the minor protein components of the rat sperm tail ODF can be isolated to homogeneity, as shown by single bands on stained gels. This capacity has enabled the determination of the amino acid composition of a number of the ODF proteins and has facilitated comparisons with the results of other studies. Unfortunately, sequencing was not successful, presumably due to $\mathrm{NH}_{2}$-terminal blocking of these proteins, and internal sequencing after cyanogen bromide or tryptic digestion was not possible due to insufficient material.

The present study showed that the rat ODF was composed of seven major bands of $84,79,32,29,26,22$ and $15.5 \mathrm{kDa}$, similar to the results of previous reports (Oko,1988; Vera et al., 1984; Olson and Sammons 1980). The largest band of $25 \mathrm{kDa}$ (Olson and Sammons, 1980) was subdivided into two bands by Vera et al. (1984) and Oko (1988) and, in the present study, it was possible to subdivide it into three bands of 32 , 29 and $26 \mathrm{kDa}$. The $13 \mathrm{kDa}$ protein reported by Vera et al. (1984) was not found in the present study. Oko (1988) described this protein as a possible contamination from the perforatorium of the sperm heads, since the isolation procedure used by Vera et al. (1984) used intact spermatozoa for the ODF extraction.

There was apparent degradation of the isolated 54 and $48.5 \mathrm{kDa}$ bands into $26 \mathrm{kDa}$ bands. Although this phenomenon was not investigated in detail (for example, to test whether all of the higher molecular weight proteins became $26 \mathrm{kDa}$ ), it indicates that these two protein bands may be dimers of a $26 \mathrm{kDa}$ protein that undergoes spontaneous cleavage under the present conditions of storage.

The amino acid composition of the ODFs is similar to that reported by Olson and Sammons (1980) and Vera et al. (1984), although there were some variations among the studies. It has been reported that the medulla of the ODF are rich in cysteine and proline (Olson and Sammons, 1980; Vera et al., 1984). In the present study, the cysteine content was high in the 22 and $15.5 \mathrm{kDa}$ proteins but comparatively low in the $26 \mathrm{kDa}$ protein. Proline was lower in the 22 and $15.5 \mathrm{kDa}$ proteins in comparison with data from previous studies (Olson and Sammons, 1980; Vera et al., 1984).

Western blotting demonstrated that there were few, if any, common epitopes between the rat FS and the rat ODF, and that there were species differences in the pattern of staining observed with whole sperm extracts. It was only the principal piece of the human spermatozoon that showed strong crossreactivity with the ODF antiserum. This observation may be explained by the fact that the ODF extend for a greater distance down the principal piece in human spermatozoa (Holstein and Roosen-Runge, 1981), or that the human FS structure allows the penetration of antibody more easily than the rat or rabbit FS. Alternatively, there may be an epitope in the human FS that crossreacts with the antiserum. The perforatorium of rat sperm heads also showed crossreactivity with the ODF antiserum by immunocytochemistry. It is possible that this crossreactivity represents the outcome of contamination of the ODF preparation used to raise the antiserum with sperm heads. It has also been reported that the perforatorium shares antigenic determinants with the FS and ODF, these structures having a $16 \mathrm{kDa}$ polypeptide in common (Oko and Clermont, 1988). However, a previous study from our group did not detect specific crossreactivity between an antiFS antiserum and the perforatorium or with the ODF (Kim et al. 1995). In the present study, only the 26 and $32 \mathrm{kDa} F S$ 
Table 2. Amino acid composition of the rat sperm total outer dense fibres (ODF) and the isolated protein components identified by apparent molecular mass

\begin{tabular}{|c|c|c|c|c|c|c|c|c|}
\hline Amino acid residue & Total ODF & $66.2 \mathrm{kDa}$ & $57.2 \mathrm{kDa}$ & $32 \mathrm{kDa}$ & $29 \mathrm{kDa}$ & $26 \mathrm{kDa}$ & $21.5 \mathrm{kDa}$ & $15.5 \mathrm{kDa}$ \\
\hline Alanine & 4.22 & 6.09 & 6.67 & 3.19 & 4.19 & 3.91 & 6.31 & 5.12 \\
\hline Arginine & 5.49 & 5.66 & 5.00 & 8.17 & 8.04 & 9.28 & 3.81 & 6.07 \\
\hline Cysteine & 11.48 & 10.21 & 6.97 & 2.31 & 9.02 & 4.41 & 12.38 & 13.12 \\
\hline Giutamic acid & 10.12 & 14.13 & 14.33 & 9.82 & 8.50 & 11.23 & 9.94 & 9.23 \\
\hline Glycine & 12.37 & 12.32 & 9.89 & 9.06 & 8.72 & 9.68 & 11.87 & 6.41 \\
\hline Leucine & 6.54 & 6.65 & 12.34 & 8.31 & 9.36 & 7.80 & 6.72 & 9.53 \\
\hline Lysine & 2.91 & 4.95 & 5.64 & 2.44 & 4.07 & 5.83 & 4.69 & 5.28 \\
\hline Methionine & 2.81 & 0.73 & 1.26 & 0.47 & 0.43 & 0.47 & 2.44 & 0.63 \\
\hline Phenylalanine & 1.54 & 1.40 & 3.50 & 2.05 & 2.00 & 2.45 & 3.04 & 3.12 \\
\hline Proline & 6.56 & 4.23 & 1.83 & 12.79 & 7.34 & 4.26 & 3.29 & 5.45 \\
\hline
\end{tabular}

Table 3. Comparison of amino acid composition of rat sperm outer dense fibres in the present and two previous studies

\begin{tabular}{|c|c|c|c|c|c|c|c|c|c|}
\hline \multirow[b]{2}{*}{$\begin{array}{l}\text { Amino acid } \\
\text { residue }\end{array}$} & \multicolumn{3}{|c|}{$26 \mathrm{kDa}($ mole $\%)$} & \multicolumn{3}{|c|}{ b22 kDa (mole \%) } & \multicolumn{3}{|c|}{${ }^{\prime} 15.5 \mathrm{kDa}($ mole $\%)$} \\
\hline & $\begin{array}{c}\text { Olson and } \\
\text { Sammons, } \\
1980\end{array}$ & $\begin{array}{c}\text { Vera et al., } \\
1984\end{array}$ & $\begin{array}{l}\text { Present } \\
\text { study }\end{array}$ & $\begin{array}{c}\text { Olson and } \\
\text { Sammons, } \\
1980\end{array}$ & $\begin{array}{c}\text { Vera et al., } \\
1984\end{array}$ & $\begin{array}{l}\text { Present } \\
\text { study }\end{array}$ & $\begin{array}{c}\text { Olson and } \\
\text { Sammons, } \\
1980\end{array}$ & $\begin{array}{c}\text { Vera et al., } \\
1984\end{array}$ & $\begin{array}{c}\text { Present } \\
\text { study }\end{array}$ \\
\hline Alanine & 2.1 & 1.8 & 3.91 & 1.9 & 1.7 & 6.31 & 1.9 & 1.9 & 5.12 \\
\hline Arginine & 8.9 & 7.5 & 9.28 & 9.2 & 6.4 & 3.81 & 9.7 & 10.8 & 6.07 \\
\hline Aspartic acid & 10.2 & 9.6 & 15.92 & 8.6 & 9.1 & 13.91 & 5.0 & 6.6 & 10.60 \\
\hline Cysteine & 12.6 & 11.5 & 4.41 & 10.1 & 12.5 & 12.38 & 11.4 & 10.2 & 13.12 \\
\hline Glutamic acid & 3.5 & 5.8 & 11.23 & 3.6 & 5.7 & 9.94 & 3.2 & 5.9 & 9.23 \\
\hline Glycine & 6.8 & 6.0 & 9.68 & 5.4 & 9.4 & 11.87 & 6.6 & 5.0 & 6.41 \\
\hline Histidine & 1.1 & 0.9 & 0.52 & 1.4 & 0.7 & 2.14 & 1.1 & 1.7 & 1.87 \\
\hline Isoleucine & 3.8 & 3.6 & 3.59 & 4.1 & 2.9 & 3.34 & 3.5 & 3.0 & 4.09 \\
\hline Leucine & 11.0 & 10.0 & 7.80 & 10.5 & 6.3 & 6.72 & 10.3 & 9.5 & 9.53 \\
\hline Lysine & 7.0 & 5.6 & 5.83 & 8.3 & 5.6 & 4.69 & 6.3 & 5.0 & 5.28 \\
\hline Methionine & 0.7 & 1.3 & 0.47 & 0.6 & 1.3 & 2.44 & nd & 1.3 & 0.63 \\
\hline Phenylalanine & 1.4 & 1.6 & 2.45 & 1.5 & 2.1 & 3.04 & 1.8 & 1.8 & 3.12 \\
\hline Proline & 11.3 & 10.3 & 4.26 & 9.2 & 11.9 & 3.29 & 15.2 & 10.5 & 5.45 \\
\hline Serine & 11.3 & 11.1 & 11.84 & 11.0 & 10.7 & 6.42 & 10.5 & 10.2 & 7.45 \\
\hline Threonine & 2.1 & 2.0 & 3.04 & 2.4 & 2.9 & 3.32 & 4.4 & 4.0 & 4.89 \\
\hline Tyrosine & 0.7 & 5.8 & 2.93 & 4.8 & 4.6 & 1.94 & 7.4 & 9.6 & 3.34 \\
\hline Valine & 5.7 & 5.6 & 2.88 & 7.4 & 6.1 & 4.73 & 1.6 & 2.9 & 3.38 \\
\hline
\end{tabular}

nd: not determined.

'Represents $25 \mathrm{kDa}$ of Olson and Sammons (1980), and $26 \mathrm{kDa}$ of Vera et al. (1984); 'Represents $19 \mathrm{kDa}$ of Olson and Sammons (1980), and 18.4 kDa of Vera et al. (1984); 'Represents $11.5 \mathrm{kDa}$ of Olson and Sammons (1980), and 11.5 kDa of Vera ef al. (1984).

proteins showed weak crossreactivity with the ODF antiserum, indicating the preparation of FS used by Oko and Clemont (1988) contained some components of the ODF, such as the $16 \mathrm{kDa}$ peptide. The results from the present study indicated that the rat perforatorium and ODF share common epitopes but that the FS does not. The amino acid composition of the rat ODF was analysed by isolating individual proteins. However, it is impossible to determine the relationships between either the ODF and the FS, or between the protein components within these structures, until amino acid sequence data is available.

Immunocytochemical studies using anti-perforatorium antibodies by Oko and Clermont (1988) indicated that, although the perforatorium is structurally continuous in forming the perinuclear theca with the postacrosomal dense lamina, it is immunologically distinct from the postacrosomal dense lamina. However, it appears to be immunologically similar to a substance found between the plasmalemma and 

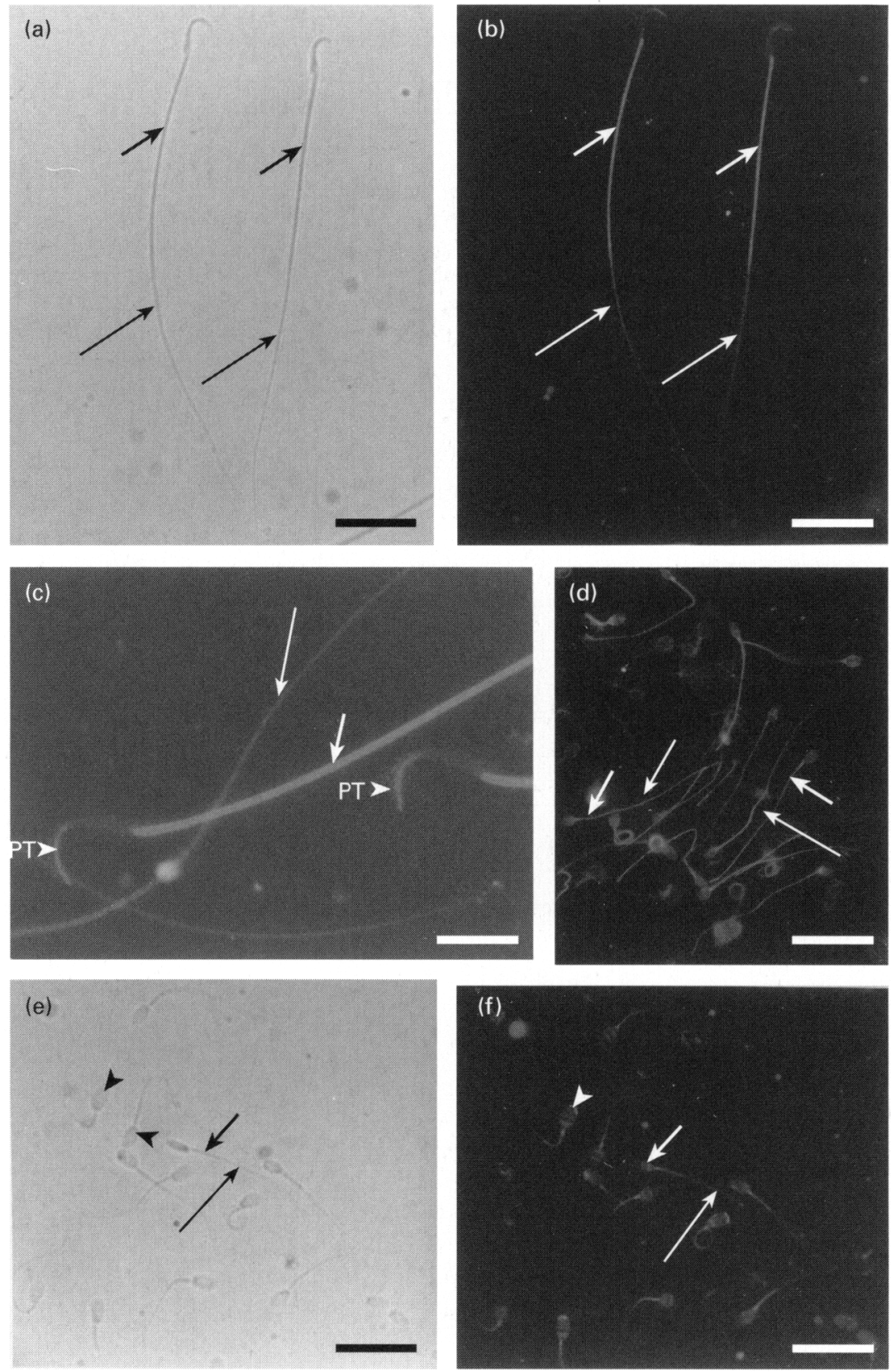

Fig. 4. Immumofluorescence localization of rat, human and rabbit sperm components with the rat sperm tail outer dense fibre antiserum. Phase-contrast micrographs of rat (a) and rabbit (e) spermatozoa, and the same fields after staining with rabbit anti-rat sperm tail outer dense fibre serum. The mid-piece (short arrow) of the rat (b) and rabbit (f) spermatozoa show crossreactivity with rat outer dense fibrous antiserum. (c) Rat spermatozoa at higher magnification showing specific staining of the perforatorium (PT) and (d) human spermatozoa showing specific immunofluorescence along the principal piece (large arrow). Scale bars represent (a,b) $16 \mu \mathrm{m}$. (c) $10 \mu \mathrm{m}$, (d-f) $25 \mu \mathrm{m}$.

outer acrosomal membrane, and also to a substance found on the inner aspect of the ventral spur. The amino acid sequence of the $15 \mathrm{kDa}$ perinuclear thecal polypeptide (PERF 15) has been reported by Oko and Morales (1994). This protein belongs to a family of fatty acid binding proteins, with a $61 \%$ sequence similarity to myelin $\mathrm{P} 2$, a $58 \%$ sequence similarity to adipocyte lipid binding protein, and a $47 \%$ similarity to the heart fatty acid-binding protein (Oko and Morales, 1994). The homology with the myelin P2 protein, which has been implicated in the induction of experimental autoimmune neuritis, indicates that the PERF 15 protein may interact with the membrane of the acrosome and play a major role in the 


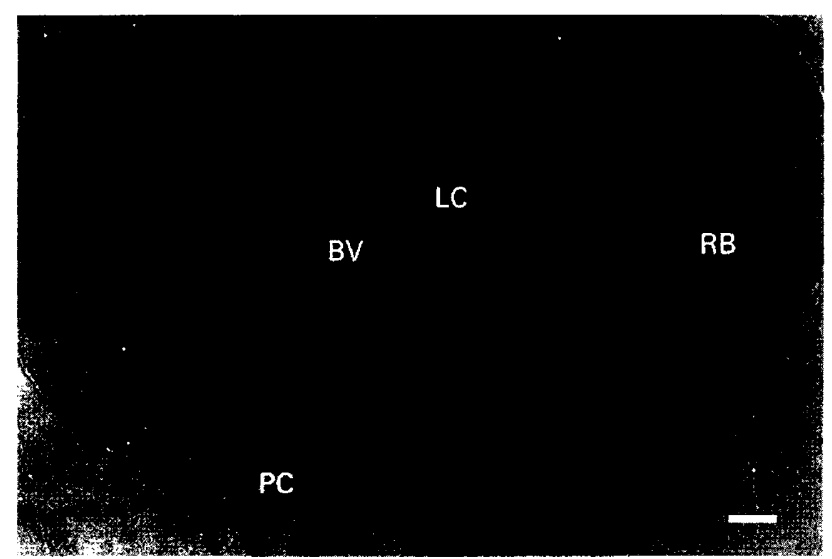

Fig. 5. Immunostaining of an adult rat testis section with a polyclonal antibody to rat sperm tail outer dense fibre. LC, Leydig cells; BV, blood vessels; PC, peritubular cells; RB, residual bodies. Scale bar represents $12 \mu \mathrm{m}$.

structural arrangement and stability of this organelle (Oko and Morales, 1994).

Immunohistochemical studies with the ODF antiserum showed that the reaction product was found in elongating spermatids from step 11 onwards with peak concentrations at stage 15. This observation is in accord with the results of Irons and Clermont (1982), which demonstrated the assembly of the ODF system using the incorporation of radiolabelled amino acids. The persistence of the reaction product in the mid-piece of spermatozoa is consistent with the location of the ODF system in the mid-piece and with an extension into the proximal portion of the principal piece where the ODFs attenuate.

Further studies on the manner in which the individual components of the ODF accumulate during spermiogenesis must await the isolation of each protein component and the development of monospecific antisera. Achievement of this goal has been frustrated by the difficulty in obtaining aminoterminal sequence data with which to isolate the genes encoding these proteins. Alternative approaches are required to advance our knowledge further.

This work was supported in part by a grant from the Victorian Health Promotion Foundation and the NH \& MRC of Australia. Y. H. Kim was supported by an overseas postgraduate award and $\mathrm{M}$. K. O'Bryan was a recipient of a postdoctoral fellowship from the NH \& MRC of Australia.

\section{References}

Almahbobi G and Hall P (1993) Indirect immunofluorescence modified to display two antigens with one light filter Histochemical journal 25 14-18

Baccetti B, Pallini V and Burrini AG (1973) The accessory fibres of the sperm tail I. Structure and chemical composition of bull coarse fibres Journal of Submicroscopy and Cytology 5 237-256

Baltz JM, Williams PO and Cone RA (1990) Dense fibers protect mammalian sperm against damage Biology of Reproduction 43 485-491
Brohmann H, Pinnecke S and Hoyer-Fender S (1997) Identification and characterization of new CDNAs encoding outer dense fiber proteins of rat sperm Journal of Biological Chemistry 272 10 327-10 332

Burfeind $\mathbf{P}$ and Hoyer-Fender $\mathbf{S}$ (1991) Sequence and developmental expression of a mRNA encoding a putative protein of rat sperm outer dense fibers Developmental Biology 148 195-204

Burfeind P, Belgardt B, Szpirer C and Hoyer-Fender S (1993) Structure and chromosomal assignment of a gene encoding the major protein of rat sperm outer dense fibres European Journal of Biochemistry 216 497-505

Calvin HI (1976) Isolation and subfractionation of mammalian sperm heads and tails. In Methods in Cell Biology Vol. XIII pP 85-104 Ed. DM Prescott. Academic Press, New York

Cohen SA and Strydom DJ (1988) Amino acid analysis utilising phenylisothiocyanate derivatives Analytical Biochemistry 174 1-16

Fawcett DW (1970) A comparative view of sperm ultrastructure Biology of Reproduction Supplement 2 90-126

Fawcett DW (1975) The mammalian spermatozoon Developmental Biology 44 394-436

Haidl G Becker A and Henkel R (1991) Poor development of outer dense fibres as a major cause of tail abnormalities in the spermatozoa of asthenoteratoxoospermic men Human Reproduction 6 1431-1438

Holstein AF and Roosen-Runge EC (1981) Atlas of Human Spermatogenesis Grosse, Berlin

Hunkapiller MW, Lujan E, Ostrander F and Hood LE (1983) Isolation of microgram quantities of proteins from polyacrylamide gels for amino acid sequence analysis Methods in Enzymology 91 227-247

Irons MJ and Clermont Y (1982) Formation of the outer dense fibres during spermiogenesis in the rat Anatomical Record 202 2463-2471

Jassim A (1991) AJ-p97: a novel antigen of the human sperm tail fibrous sheath detected by a neurofulament monoclonal antibody lournal of Reproductive Immunology $2015-26$

Kim YH, McFarlane JR, Almahbobi G, Stanton PG, Temple-Smith PD and de Kretser DM (1995) Isolation and partial characterization of rat sperm tail fibrous sheath proteins and comparison with rabbit and human spermatozoa using a polyclonal antiserum Journal of Reproduction and Fertility 104 107-114

Laemmli UK (1970) Cleavage of structural proteins during the assembly of the head of bacteriophage $T_{4}$ Nature 227 680-685

Lowry OH, Rosenbrough NJ, Farr AL and Randall RJ (1951) Protein measurement with the folin phenol reagent Journal of Biological Chemistry $193265-275$

Oko R (1988) Comparative analysis of proteins from the fibrous sheath and outer dense fibers of rat spermatozoa Biology of Reproduction 39 169-182

Oko $R$ and Clermont $Y$ (1988) Isolation, structure and protein composition of the perforatorium of rat spermatozoa Biology of Reproduction 39 673-687

Oko R and Morales C (1994) A novel testicular protein, with sequence similarities to a family of lipid binding proteins, is a major component of the rat sperm perinuclear theca Developmental Biology $166235-245$

Olson GE and Sammons DW (1980) Structural chemistry of outer dense fibers of rat sperm Biology of Reproduction 22 319-332

Price M (1973) Biochemical and morphological studies of the outer dense fibers of rat spermatozoa Journal of Cell Biology $59272 a$

Shao X, Tarnasky HA, Schalles U, Oko R, van der Hoorn FA (1997) Interactional cloning of the $84-\mathrm{kDa}$ outer dense fiber protein Odf84 leucine zippers mediate associations of Odf84 and Odf27 journal of Biological Chemistry 272 6105-6113

Stanton PG, Robertson DM, Burgon PG, Schmauk-White and Hearn MT (1992) Isolation and physiochemical characterization of follicle stimulating hormone isoforms Endocrinology 130 2820-2832

Towbin H, Staehelin T and Gordon J (1979) Electrophoretic transfer of proteins from polyacrylamide gels to nitrocellulose sheets: procedure and some applications Procedings National Academy of Sciences USA 76 4350-4354

Vera JC, Brito M, Zuvic T and Burzio LO (1984) Polypeptide composition of rat sperm outer dense fibers. A simple procedure to isolate the fibrillar complex Journal of Biological Chemistry 259 5970-5977

Wray W, Boulikas T, Wray VP and Hancock R (1981) Silver staining of proteins in polyacrylamide gels Analytical Biochemistry 118 197-203 